Farsat Ali SHABAN

Dilgash Q. Mohamed SALIH

Waleed Ali Hussein AL-ZAIDI

\title{
2.4. THE IMPACT OF CREATIVITY ELEMENTS ON EDUCATIONAL SERVICE - A CASE STUDY FROM IRAQ
}

\begin{abstract}
Summary
This study aims to determine the impact of creativity elements on educational service quality dimensions depending on the hypothetical scheme takes into account the correlation between two variables, and adopted two fundamental hypotheses to determine the impact and correlation between research variables. The theoretical side of the research was written by taking advantage of the literature of the relative subject. Duhok Polytechnic University in Iraqi-Kurdistan Region has been chosen to conduct the field part of the study; research sample consist of 70 individuals of academic staff of the chosen university. A questionnaire has been developed to collect data and information on the field side, and through using statistical methods (frequencies, percentages, mean standard deviation, Spearman's rank correlation and regression analysis). The descriptive data have been analyzed and research hypotheses have been tested. The most important findings of the study were: the emergence of attention and concern by the university to the concept of creativity reflected in their answers that creativity elements have a significant positive impact on educational service quality dimensions and a significant positive correlation has been proved between them as well. The study reached a set of proposals the most important is to try to take advantage of the strengths owned by the university regarding the elements of creativity that the results showed a clear impact on the services provided, especially originality and sensitivity to problems variables.
\end{abstract}

Keywords: creativity elements, educational service quality dimensions, higher education

\section{Introduction}

In today's competitive academic environment, higher education institutions all over the world face massive challenges. It is not a secret that higher education is more competitive than ever, because of the globalization and the new technology which affects all aspects of today's business environment especially in higher education sector. Quality of services which universities offer at present, become the matter which cannot be avoided. Service quality has been extended from business to education. Many universities have been affected by service quality both for teaching and administrative support functions. Universities struggling to get competitive advantage and this goal can be achieved through discovering new and creative methods in 
teaching and learning, and providing appropriate means and materials in order to offer the best services which characterized by flexibility and adaptability. The idea of this study comes from here. Therefore, the study tries to investigate the impact of creativity elements on educational service quality dimensions in Duhok Polytechnic University.

\section{Research problem}

The creativity dimensions are not the matter of consideration by academic staff in Duhok Polytechnic University which will affect the quality of services that university offer to their customers. And the result will be the failure of the university to compete in education business especially after the reforms in education system started by the ministry of higher education and scientific research in Kurdistan Regional Government.

The main question of this study was the following: Is there an impact of the creativity elements on educational service quality?

Two additional questions were formed based on the main question:

First question: To what extent the academic staff in Duhok Polytechnic University is aware about the creativity elements in teaching process?

Second question: Is there an impact of the creativity elements on educational service quality?

\section{Literature review}

\section{Elements of creativity}

The role of creativity and creative employees for organizations' performance growth cannot be overlooked in today's competitive dynamic world (Ul Hassan et al. 2013). Amabile (2012) defined creativity as the production of a novel and appropriate response, product, or solution to an open-ended task. John (2004) proposed creativity as the ability of people, and then the ability of employees, to combine ideas in a unique way or to make unusual associations between ideas. Creativity is the ability to think in ways and forms that are new, different and not seen in other individuals (Bosiok et al. 2013). By summarizing the above definitions and explanations, we can say that creativity is the ability of a person or employee to produce and generate useful and novel ideas concerning products, services, and processes or solving problems.

By reviewing previous studies and literature related to the topic of creativity, we could find that most of the researchers and authors are agree about these four main elements of creativity (Figure 1.) 
Figure 1: Four elements of creativity

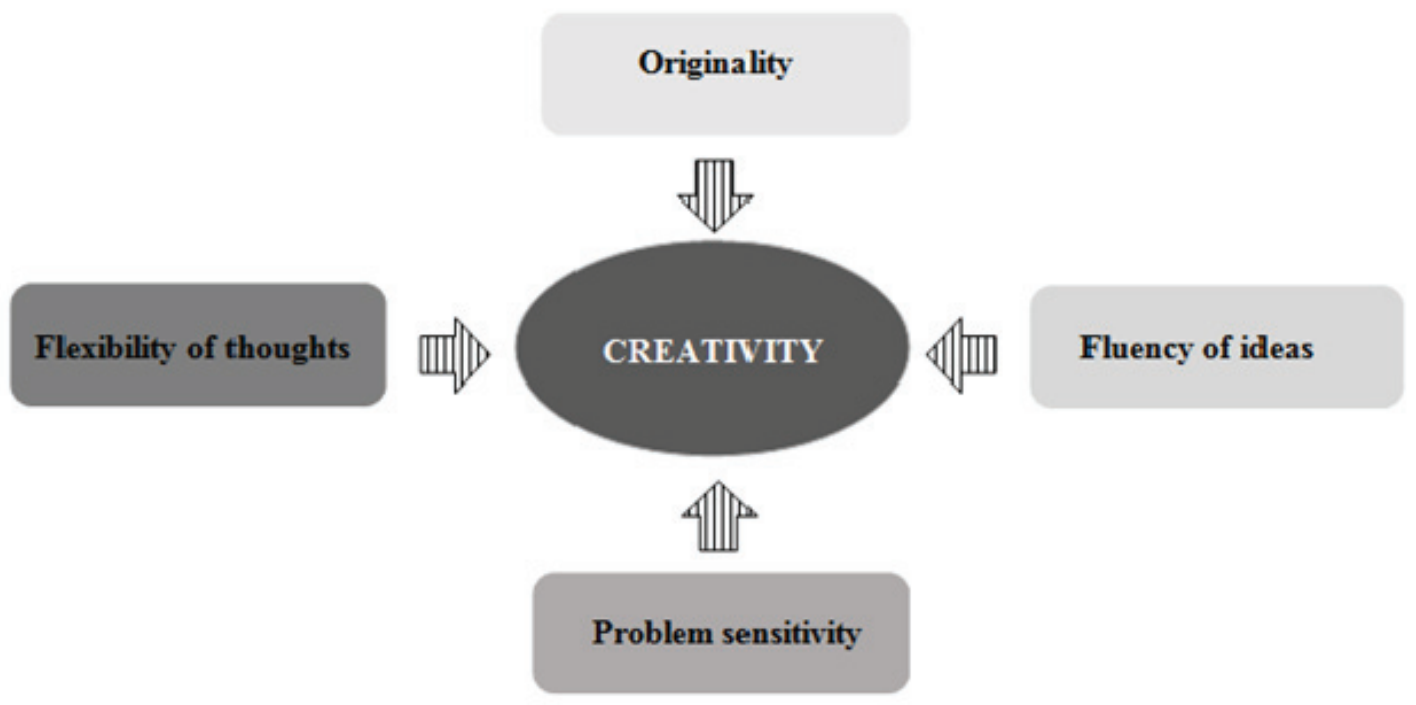

Source: own composition

Originality is the quality that creates unique or extraordinary thoughts, unusual ideas, or the first of a kind Shively (2011). Flexibility of thoughts is the individual's ability to change the method or suggest a variety of different approaches toward a problem or situation. Fluency of ideas is the first step of creative endeavour or problem solving. If ideas may be generated by different tools and methods, and they shall be examined or evaluated, are they formulate opportunities, or are they feasible or not (Shively, 2011). Finally, problem sensitivity is an ability to determine problems and being aware about the needs for change or for new approaches or methods (Se Kim et al., 2008).

\section{Service Quality}

The higher education industry all over the world has undergone massive growth in recent years, mainly to keep the moderate level of the proposed educational services. Service quality defined by Gržinić (2007) as the way to manage business processes in order to ensure customer satisfaction. The improvement of service quality in higher education institutions lies in the institution's ability to provide an overall climate and culture for change through its different operating systems, decision-making systems, and human resource practices Mosadeghard (2006).

Based on the deeply review, many dimensions of service quality have been founded by authors in different sectors, while the most widely accepted model by researchers is the five dimensions of service quality (SERVQUAL) which has been developed by Parasuraman et al. (1985). Firstly they determined ten dimensions of service quality. In a refined study in 1988, Parasuraman et al. reduced the number of service quality dimensions from ten to five, contending that these five components completely capture 
the service quality field. According to them, the five final service quality dimensions are Çerri (2012):

1. Reliability: ability to achieve the promised service accurately and dependability;

2. Responsiveness: readiness provide on time service;

3. Assurance: ability of a service firm to encourage trust and confidence through knowledge and courtesy of employees;

4. Tangibles: appearance of a service firm's physical facilities, equipment and appearance of employees;

5. Empathy: willingness and capability to give individualized attention to customers.

\section{Methodology}

The methodology of this study depends on the resources and previous studies to cover the theoretical part, while the practical part will be covered through statistical methods to analyze the collected data through Statistical Packages of the Social Science (SPSS).

\section{Research framework and hypotheses}

Stages and scope of the research is detailed in Figure 1.

Figure 1: Research framework

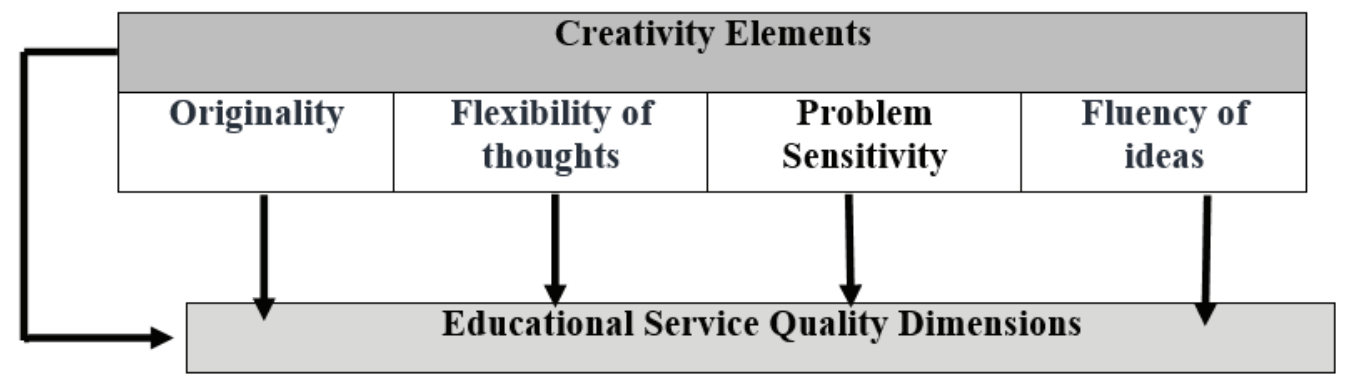

Source: own

Two main hypotheses were set, with four sub-hypotheses in each:

$\mathrm{H} 1$ : there is a significant correlation between the elements of creativity variables and educational service quality dimensions.

- H1a: There is a significant correlation between fluency of ideas and educational service quality dimension.

- H1b: There is a significant correlation between flexibility of thoughts and quality and educational service quality dimension

- H1c: There is a significant correlation between sensitivity to problems and educational service quality dimensions.

- H1d: There is a significant correlation between originality element and educational service quality dimensions. 
$\mathrm{H} 2$ : Creativity elements have a significant impact on educational service quality dimensions. And it is differ from one element to another.

- H2a: Fluency of ideas has a significant positive impact on educational service quality dimensions

- H2b: Flexibility of thoughts has a significant positive impact on educational service quality dimensions.

- H2c: Problem sensitivity has a significant positive impact on educational service quality dimensions.

- H2d: originality has a significant positive impact on educational service quality dimensions

\section{Population and sampling}

Universities are the most crucial sources to enhance societies from successful and creative people, and the educated and developed societies are tied to the outputs of universities.

This study chooses Duhok Polytechnic University as a population of the study, because it is one of the newest universities in Kurdistan Region, and tries to improve its staffs and it pays a significant attention to the issue of service quality. The sample of the study is the academic staff of the university.

Eighty questionnaires were distributed to the academic staff of the university and seventy completed and usable questionnaires were collected representing a response rate of $87 \%$. Table 1 shows the analysis of demographic details of the survey respondents.

Table 1: Demographic features of the sample

\begin{tabular}{|l|l|c|c|c|}
\hline \multirow{3}{*}{ Gender } & \multicolumn{3}{|l|}{ Male } & Female \\
\cline { 2 - 5 } & No. & $\%$ & No. & $\%$ \\
\cline { 2 - 5 } & 52 & $\mathbf{7 4 . 2}$ & 18 & $\mathbf{2 5 . 8}$ \\
\hline
\end{tabular}

\begin{tabular}{|c|c|c|c|c|c|c|}
\hline \multirow{3}{*}{ Age } & \multicolumn{2}{|c|}{$26-30$} & \multicolumn{2}{c|}{$31-35$} & \multicolumn{2}{c|}{36 and more } \\
\cline { 2 - 7 } & No. & $\mathbf{\%}$ & No. & $\mathbf{\%}$ & No. & $\mathbf{\%}$ \\
\cline { 2 - 7 } & $\mathbf{6}$ & $\mathbf{1 6}$ & $\mathbf{2 0}$ & $\mathbf{9}$ & $\mathbf{1 6}$ & $\mathbf{3 5}$ \\
\hline
\end{tabular}

\begin{tabular}{|c|c|c|c|c|c|c|}
\hline \multirow{3}{*}{ Educational level } & \multicolumn{2}{|c|}{$\mathrm{PhD}$} & \multicolumn{2}{c|}{ Master } & \multicolumn{2}{c|}{ Other diploma } \\
\cline { 2 - 7 } & No. & $\mathbf{\%}$ & No. & $\mathbf{\%}$ & No. & $\%$ \\
\cline { 2 - 7 } & $\mathbf{4}$ & $\mathbf{6}$ & $\mathbf{6 2}$ & $\mathbf{8 8}$ & $\mathbf{4}$ & $\mathbf{6}$ \\
\hline
\end{tabular}

\begin{tabular}{|l|c|c|c|c|c|c|}
\hline \multirow{3}{*}{ Position } & \multicolumn{2}{|c|}{ Associate professor } & \multicolumn{2}{c|}{ Assistant professor } & \multicolumn{2}{c|}{ Assistant lecturer } \\
\cline { 2 - 7 } & No. & $\mathbf{\%}$ & No. & $\mathbf{\%}$ & No. & $\%$ \\
\cline { 2 - 7 } & $\mathbf{2}$ & $\mathbf{3}$ & $\mathbf{1 0}$ & $\mathbf{1 4}$ & $\mathbf{5 8}$ & $\mathbf{8 3}$ \\
\hline
\end{tabular}

\begin{tabular}{|c|c|c|c|c|c|c|c|c|}
\hline \multirow{3}{*}{$\begin{array}{c}\text { Years of } \\
\text { working } \\
\text { experience }\end{array}$} & \multicolumn{2}{|c|}{16 and more } & \multicolumn{2}{|c|}{$11-15$} & \multicolumn{2}{c|}{$6-10$} & \multicolumn{2}{c|}{$1-5$} \\
\cline { 2 - 9 } & No. & $\mathbf{\%}$ & No. & $\mathbf{\%}$ & No. & $\mathbf{\%}$ & No. & $\%$ \\
\cline { 2 - 9 } & $\mathbf{8}$ & $\mathbf{1 1}$ & $\mathbf{1 3}$ & $\mathbf{1 9}$ & $\mathbf{2 3}$ & $\mathbf{3 3}$ & $\mathbf{2 6}$ & $\mathbf{3 7}$ \\
\hline
\end{tabular}




\section{Data collection and data analysis}

We used both primary and secondary data for this study. Primary data was collected through structured questionnaire. This method is good as it gives the researchers the opportunity to clarify any ambiguities in the instrument. The questionnaire was developed by the research team based on the literature review on the related topics. The questionnaire consists of three parts; the first part contains information related to the demographic of the targeted survey participants.

The second section of the questionnaire looks for the measurement of independent variables (components of creativity). It contains (20) questions, for each component (5) questions.

The third part of the questionnaire holds the measurement of dependent variable (educational service quality dimensions). It includes (25) questions for each dimension (5) questions.

Two survey instruments used in this study to investigate the correlation between dependent and independent variables. Respondents of this questionnaire will rank questions based on a five-point Likert scale (5: Strongly agree, 4: Agree, 3: Sometimes agree, 2: Disagree, 1: Strongly disagree).

\section{Data Analysis}

This part includes testing both correlation hypothesis and impact hypothesis of the study.

\section{First: Testing correlation hypothesis}

The content of the first main hypothesis indicates that there is a significant correlation between the elements of creativity variables and educational service quality dimensions.

Table 2. The values of simple correlation coefficient between the elements of creativity variables and educational service quality dimensions

\begin{tabular}{|c|l|l|l|l|l|}
\hline $\begin{array}{c}\text { I.V. } \\
\text { (Creativity elements) }\end{array}$ & Originality & $\begin{array}{l}\text { Problem } \\
\text { Sensitivity }\end{array}$ & $\begin{array}{l}\text { Flexibility } \\
\text { of thoughts }\end{array}$ & $\begin{array}{l}\text { Fluency } \\
\text { of ideas }\end{array}$ & $\begin{array}{l}\text { Total } \\
\text { index }\end{array}$ \\
\hline $\begin{array}{c}\text { D.V. } \\
\text { (educational service } \\
\text { quality) }\end{array}$ & $* * 0.427$ & $* * 0.409$ & $* * 0.147$ & $* * 0.281$ & $* * 0.429$ \\
\hline
\end{tabular}

Source: own data

The results from Table 2 show that there is a significant positive correlation between the elements of creativity as independent variables and educational service quality dimensions as dependent variable, the strength of the correlation coefficient (total index) for them reached (0.429) at the significant level (0.01). As the table indicates that the strength of the correlation coefficient varies from one variable to another. 
Originality variable received the highest value among the independent variables and the value of the correlation coefficient $(0.427)$ at the significant level $(0.01)$, followed by the sensitivity to the problems variable, which the value of the correlation coefficient reached (0.409) at the significant level (0.01). Fluency variable comes thirdly reaching the value of the correlation coefficient $(0.281)$ at the significant level (0.01).

The correlation between flexibility of thoughts variable and service quality dimensions also positive but it is less correlated than the other three variables, the value of the correlation coefficient of the flexibility variable (0.147) at the significant level (0.01).

Thus the first main hypothesis is accepted which states (there is a significant correlation between the elements of creativity combined and educational service quality dimensions). Similarly, the first group of sub-hypothesis are accepted based on the finding in Table 2.

\section{Second: Testing impact hypothesis}

The content of the second main hypothesis indicates that elements of creativity variables have a significant impact on educational service quality dimensions.

Table 3: analysis of correlation impact of combined creativity elements on educational service quality dimensions

\begin{tabular}{|c|c|c|c|c|c|c|}
\hline Creativity elements & Beta & $\mathrm{B}$ & $\mathrm{R}^{2}$ & $\mathrm{~T}$ & $\mathrm{~F}$ & $\begin{array}{c}\text { Significance } \\
\text { level }\end{array}$ \\
\hline $\begin{array}{c}\text { Educational service } \\
\text { quality }\end{array}$ & 0.472 & 0.585 & 0.18 & 3.919 & 15.360 & 0.000 \\
\hline $\mathrm{P} \leq 0.01 \quad \mathrm{~N}=70$ & Source: own data
\end{tabular}

The results from the above table which is concerning to the results of regression analysis which shows that there is a significant positive impact of independent variables (combined elements of creativity) as explanatory variables on educational service quality dimensions as responsive variables. Which indicates by results of analysis of regression coefficient (B) and the value of (F-test) that is (15.360) and the significance level of (P-value) is $(0.000)$ which is less than the statistical significance level of this study which is $(0.01)$.

Through noticing the value of (B) which is (0.585) with support of (T) show that the value of (T-test) is (3.919) and the significance level is (0.000), it is a positive significant level at significant level (0.01).

Thus the second main hypothesis is accepted which states (the elements of creativity variables have a significant impact on educational service quality dimensions)

While the impact correlation of each element of creativity separately on educational service quality dimensions illustrated in Table 3. 
Table 4: Analysis of impact correlation of the elements of creativity on educational service quality dimensions

\begin{tabular}{|l|c|c|c|c|c|c|}
\hline \multirow{2}{*}{ Creativity elements } & \multicolumn{5}{|c|}{ Educational service quality dimensions } \\
\cline { 2 - 7 } & $\mathrm{F}$ & $\mathrm{T}$ & $\mathrm{R}^{2}$ & $\mathrm{~B}$ & Beta & Sig. \\
\hline Fluency of ideas & 5.821 & 2.413 & 0.079 & 0.462 & 0.281 & 0.009 \\
\hline Flexibility of thoughts & 1.500 & 3.783 & 0.022 & 0.236 & 0.146 & 0.000 \\
\hline Problem Sensitivity & 13.662 & 3.696 & 0.167 & 0.565 & 0.409 & 0.003 \\
\hline Originality & 19.446 & 4.410 & 0.222 & 0.587 & 0.472 & 0.000 \\
\hline $\mathrm{P} \leq 0.01 \quad \mathrm{~N}=70$ & & & & & & \\
\hline
\end{tabular}

Source: own data

The findings in Table 4 show that there is significant positive impact of the first variable of the elements of creativity (fluency of ideas) on the educational service quality dimensions which indicates by results of analysis of regression coefficient (B). The value of (F-test) that is (5.821) and the significance level is (0.009) which is less than the statistical significance level of this study which is $(0.01)$.

Supported by the value of the coefficient of determination R2 which is $(0.079)$ this means that the fluency variable contribute and interpret $(7.9 \%)$ of the variation founded in educational service quality variable. Through observing the value of (B) which is (0.585) with support of (T) show that the value of (T-test) is (3.919) and the significance level is (0.000), it is a positive significant level at significant level (0.01). Thus the second sub-hypothesis is accepted, which states (there is a significant positive impact of the first variable of the elements of creativity (fluency of ideas) on the educational service quality dimensions. Likewise, the second group of sub-hypotheses are accepted depending on the results of Table 4.

\section{Conclusions}

Because of the complexities of this era and high competitiveness in business environment, this affected heavily the organizations in general and service organizations in particular, organizations who are working in service sector especially universities are looking for the necessary and modern mechanisms in order to achieve the quality of their services. Organizations that have encouraged and stimulated their individuals to adopt creative ways and methods are able to provide the educational services that characterized by appropriate quality and distinguish their services from their competitors, and through the four elements of creativity (fluency, flexibility, problem sensitivity and originality), organizations can improve the quality of service provided. These four elements considered as a roadmap for organizations that interested in the concept of creativity and tend to provide a service with adequate quality. 


\section{References}

1. Amabile, (2012): Componential Theory of Creativity, Harvard Business School, Encyclopedia of Management Theory (Eric H. Kessler, Ed.), Sage Publications, 2013.

2. Bosiok, et al. (2013). Leadership styles and creativity, Online Journal of Applied Knowledge Management, Volume 1, Issue2.

3. Çerri S. (2012): Assesing the quality of higher education services using a modified SERVQUAL scale, Annales Universitatis Apulensis Series Oeconomica, 14(2).

4. Herrmann, N. (1999): Creativity, Innovation, are they different? Do we need both? Focus Volume 10, Number 3.

5. Imran R., Zaheer A., Noreen A. (2011): Transformational leadership as a predictor of Innovative work behavior: Mediated by Gender, World Applied Sciences Journal, 14 (5): 750-795.

6. Jusoh A., Omain S.Z., Majid M.A., Som H., Shamsuddin A.S. (2004): Service quality in higher education: Management students' perspective, Research Management Centre, University of Technology Malaysia, VOT 71982.

7. Gržinić J. (2007): Concepts of service quality measurement in hotel industry, Ekonomska misao i praksa / Economic Thought and Practice XVI (1.) pp. 81-98.

8. Kabir H., Carlsson T. (2010), Service Quality, Master thesis, Gotland University.

9. Lee Y. and Tan E. (2012): The influence of antecedents on employee creativity and employee performance: A meta-analytic review, Interdisciplinary Jurnal of Contemporary Research Business, Vol 4, No.2.

10. Parasuraman A, Zeithaml VA, Berry LL (1988): SERVQUAL: A multipleitem scale for measuring consumer perceptions of service quality. J. Retailing. 64(1): 12-40.

11. Prasad and Kumar Jha, (2013): Quality Measures in Higher Education: A Review and Conceptual Model, Journal of Research in Business and Management, Volume 1. Issue 3.

12. Shauchenka (2014): Methodology and measurement system for higher education service quality estimation, International Conference on Educational Technologies and Education. 978-1-61804

13. Se Kim, Sook Kim, and Ae Park (2008). Training programs for cognitive components of creativity, International conference on engineering and product design education, Barcelona

14. Shively C.H. (2011): Grow Creativity, Learning \& Leading with Technology, Vol. 38 No. 7. pp. 10-15.

15 Ul Hassan et al. (2013):Measuring employee creativity and its impact on organization innovation capability and performance in the Banking sector of Pakistan, World Applied Sciences Journal 24 (7): 949-959. 